\title{
Comparative cytogenetic analyses in Ancistrus species (Siluriformes: a Loricariidae)
}

Correspondence:

Viviane Nogaroto vivianenogaroto@uepg.br

Submitted March 13, 2020

Accepted May 11, 2020

by Guilhermo Ortí

Epub Jun 26, 2020

\author{
${ }^{\oplus}$ Larissa Glugoski ${ }^{1},{ }^{\oplus}$ Geize Deon ${ }^{1},{ }^{\oplus}$ Stephane Schott ${ }^{2}$, \\ ${ }^{\oplus}$ Marcelo R. Vicari ${ }^{2},{ }^{\oplus}$ Viviane Nogaroto ${ }^{2}$ and \\ ${ }^{\oplus}$ Orlando Moreira-Filho'
}

Ancistrus is a specious genus of armored catfishes that has been extensively used for cytogenetic studies in the last 17 years. A comparison of the extensive karyotypic plasticity within this genus is presented with new cytogenetic analysis for Ancistrus cf. multispinis and Ancistrus aguaboensis. This study aims to improve our understanding of chromosomal evolution associated with changes in the diploid number $(2 \mathrm{n})$ and the dispersion of ribosomal DNAs (rDNAs) within Ancistrus. Ancistrus cf. multispinis and A. aguaboensis exhibit 2n of 52 and 50 chromosomes, respectively. Given that $A$. cf. multispinis shares a $2 \mathrm{n}=52$ also found in Pterygoplichthyini, the sister group for Ancistrini, a Robertsonian $(\mathrm{Rb})$ fusion event is proposed for the $2 \mathrm{n}$ reduction in A. aguaboensis. $5 \mathrm{~S}$ rDNAs pseudogenes sites have already been associated with $\mathrm{Rb}$ fusion in Ancistrus and our analysis suggests that the $2 \mathrm{n}$ reduction in $A$. aguaboensis was triggered by double strand breaks (DSBs) and chromosomal rearrangements at $5 \mathrm{~S}$ rDNA sites. The presence of evolutionary breakpoint regions (EBRs) into rDNA cluster is proposed to explain part of the $\mathrm{Rb}$ fusion in Ancistrus. Cytogenetic data presented extends the diversity already documented in Ancistrus to further understand the role of chromosomal rearrangements in the diversification of Ancistrini.

Keywords: Armored catfish, FISH, 5S rDNA, 18S rDNA, telomeric sequence.
Online version ISSN 1982-0224 Print version ISSN 1679-6225

Neotrop. Ichthyol. vol. 18, no. 2, Maringá 2020
1 Departamento de Genética e Evolução, Universidade Federal de São Carlos, Rod. Washington Luís, Km 235, $13565-905$ São Carlos, SP, Brazil. (LG) lariglugoski@hotmail.com; (GD) geizeadeon@gmail.com; (OMF) omfilho@ufscar.br.

2 Departamento de Biologia Estrutural, Molecular e Genética, Universidade Estadual de Ponta Grossa, Av. Carlos Cavalcanti, 4748, 84030-900 Ponta Grossa, PR, Brazil. (SS) stephane.qs@hotmail.com; (MRV) vicarimr@uepg.br; (VN) vivianenogaroto@uepg.br (corresponding author). 
Ancistrus é um gênero rico em espécies de peixes conhecidos como cascudos e tem sido alvo de estudos citogenéticos nos últimos 17 anos. Uma comparação da plasticidade presente no gênero é apresentada com novas análises citogenéticas para Ancistrus cf. multispinis e Ancistrus aguaboensis. Este estudo visa melhorar nossa compreensão da evolução cromossômica associada as alterações do número diploide (2n) e a dispersão de DNAs ribossômicos (rDNAs) em Ancistrus. Ancistrus cf. multispinis e A. aguaboensis apresentaram 2n de 52 e 50 cromossomos, respectivamente. Visto que $A$. cf. multispinis compartilha $2 \mathrm{n}=52$ também encontrado em Pterygoplichthyini, o grupo irmão para Ancistrini, um evento de fusão Robertsoniana $(\mathrm{Rb})$ é proposto para a redução do $2 \mathrm{n}$ em $A$. aguaboensis. Sítios de pseudogenes de rDNA $5 \mathrm{~S}$ já foram associados a eventos de fusão $\mathrm{Rb}$ em Ancistrus e nossas análises sugerem que a redução do $2 \mathrm{n}$ em A. aguaboensis foi desencadeada por quebras na dupla fita e rearranjos cromossômicos em sítios de rDNA 5S. A presença de evolutionary breakpoint regions (EBRs) em clusters de rDNA foi proposta para explicar parte da fusão Rb em Ancistrus. Os dados citogenéticos apresentados ampliam a diversidade já documentada em Ancistrus visando melhor entender o papel dos rearranjos cromossômicos na diversificação de Ancistrini.

Palavras-chave: Cascudo, FISH, rDNA 5S, rDNA 18S, sequência telomérica.

\section{INTRODUCTION}

Loricariidae is the largest family of the Siluriformes, which includes about 1.000 species distributed in the Neotropical region, and comprises fishes vulgarly called as armored catfishes (Fricke et al., 2020). It consists of six subfamilies: Delturinae, Hypoptopomatinae, Hypostominae, Lithogeninae, Loricariinae and Rhinelepinae (Armbruster, 2004; Reis et al., 2006). The former subfamily Ancistrinae was considered synonymous with Hypostominae by Armbruster (2004) and, currently, Hypostominae presents 483 valid species (Fricke et al., 2020), grouped in the tribes: Corymbophanini, Rhinelepini, Hypostomini, Pterygoplichthyini and Ancistrini (Armbruster, 2004; Lujan et al., 2015). In a systematic review study, Ancistrini was proposed to possess ten genera considered valid (Lujan et al., 2015). Previously, this tribe was distributed in a larger number of genera which ones were found to be paraphyletic, and is therefore restricted to a weakly supported clade (Lujan et al., 2015). Currently, Ancistrini remains a clade rich in genera and with a high morphological diversity (Lujan et al., 2015), which presents constant systematic reformulations and with a lot of undescribed species waiting for scientific validation.

Pterygoplichthyini was considered sister group for Ancistrini (Ambruster, 2004) and cytogenetic data demonstrated $2 \mathrm{n}$ of 52 chromosomes in Pterygoplichthyini species (Alves et al., 2006). Previous cytogenetic studies in Ancistrini also showed a large number of species with $2 \mathrm{n}=52$ chromosomes, predominantly of meta and submetacentric chromosomes (Artoni, Bertollo, 2001; de Oliveira et al., 2006). Based on phylogenetic relationships of Hypostominae proposed by Lujan et al. (2015), and considering the 
presence of $2 \mathrm{n}=52$ chromosomes in Pterygoplichthyini, the sister group for Ancistrini, Bueno et al. (2018) suggested that the putatively ancestral condition for Ancistrini is a diploid number of 52 chromosomes, from which chromosomal diversification occurred to explain the observed karyoptypic plasticity among studied species.

Ancistrus is the specious genus of Ancistrini and is widely distributed in South America (Ferraris, 2007; Armbruster, 2008; Lujan et al., 2013). In this tribe, only Ancistrus species presents a diversified condition from $2 \mathrm{n}=52$ chromosomes, with a higher frequency of acrocentric chromosomes (de Oliveira et al., 2007, 2008, 2009; Mariotto et al., 2009, 2011; Konerat et al., 2015; Favarato et al., 2016; Barros et al., 2017; Bueno et al., 2018). Cytogenetic data in Ancistrus revealed a diversity of $2 \mathrm{n}$ and karyotype formulas (details of available Ancistrus cytogenetic data can be found in Tab. 1), which range from $2 \mathrm{n}=$ 34 to 54 chromosomes (Mariotto et al., 2011). In addition, different heteromorphic sex chromosome systems are found in the genus, such as: $\mathrm{XX} / \mathrm{X} 0, \mathrm{XX} / \mathrm{XY}, \mathrm{XX} / \mathrm{XY}_{1} \mathrm{Y}_{2}$, $\mathrm{ZZ} / \mathrm{ZW}$ and $\mathrm{Z}_{1} \mathrm{Z}_{1} \mathrm{Z}_{2} \mathrm{Z}_{2} / \mathrm{Z}_{1} \mathrm{Z}_{2} \mathrm{~W}_{1} \mathrm{~W}_{2}$. In Ancistrus, with the exception of species with $2 \mathrm{n}=52$ and 54 chromosomes, it was suggested a reduction in $2 \mathrm{n}$ via $\mathrm{Rb}$ fusion events (de Oliveira et al., 2007, 2008, 2009; Mariotto et al., 2009, 2011; Konerat et al., 2015; Favarato et al., 2016; Barros et al., 2017) and structural chromosomal changes, such as inversions, translocations, deletions and duplications (Mariotto et al., 2011).

In addition to Ancistrus, other members of Loricariidae present species with 2n reduction via $\mathrm{Rb}$ fusions, when vestiges of interstitial telomeric sites (ITS) can be visualized in some karyotypes (Rosa et al., 2012; Errero-Porto et al., 2014; Favarato et al., 2016; Barros et al., 2017; Primo et al., 2017; Glugoski et al., 2018). Some of these Rb events were associated with the presence of EBRs inside $5 \mathrm{~S}$ and $45 \mathrm{~S}$ rDNAs sites, which triggered breaks and chromosomal reorganizations (Rosa et al., 2012; Barros et al., 2017; Primo et al., 2017; Glugoski et al., 2018). However, the presence of other repetitive DNA sequences, able of explaining the occurrence of other EBRs in the Loricariidae genomes, still remain uncertain (Primo et al., 2018).

Repetitive DNAs are organized as grouped blocks (microsatellites, mini-satellites, satellites and multigene families) or are dispersed (transposons and retrotransposons) on the chromosomes (Charlesworth, 1994). These repetitive sequences have been shown to be fundamental in studies related to genomic evolution (Maxon et al., 1983; Charlesworth et al., 1994; Vicari et al., 2010). Multigene families of rRNAs are composed of repetitions organized in tandem (Long, Dawid, 1980). They constitute two gene families with different loci in the karyotypes: the major rDNA $45 \mathrm{~S}$ comprises the genes that encode the 18S, 5.8S and 28S rRNAs; while the minor rDNA codifies the 5S rRNA (Long, Dawid, 1980). In situ localization of rDNA sites showed that the dispersion and distribution of these repetitive DNAs may have contributed to genomic diversification and chromosomal remodeling among armored catfish (Rosa et al., 2012; Errero-Porto et al., 2014; Barros et al., 2017; Primo et al., 2017; Glugoski et al., 2018).

Cytogenetic studies contribute to taxonomy by demonstrating difference in karyotypes of cryptic species (Vicari et al., 2006; Oliveira et al., 2016; Barbosa et al., 2017; Nascimento et al., 2018) or by detecting synonym species (Bellafronte et al., 2005). Given the morphological similarity present in some members of Ancistrus and the occurrence of a lot of scientific undescribed species in the scientific literature, the taxonomy of the group has been suffered numerous reformulations (de Oliveira et al., 2009; Lujan et al., 2015). In this study, the cytogenetic data of two species of Ancistrus were described and 
TABLE 1 I Review of available Ancistrus cytogenetic data. "Unknown" means that the data was not available in the original manuscript. NOR: Nucleolar Organizer Region; m: metacentric; sm: submetacentric; st: subtelocentric; a: acrocentric; FN: Fundamental number. *one member of the homologous pairs with FISH markers.

\begin{tabular}{|c|c|c|c|c|c|c|c|c|}
\hline Species & $2 n$ & FN & Karyotype formula & $\begin{array}{c}\text { Sex } \\
\text { chromosome } \\
\text { system }\end{array}$ & rDNA 5S (pair) & $\begin{array}{l}\text { rDNA } \\
18 S \\
\text { (pair) }\end{array}$ & Localization & Reference \\
\hline Ancistrus cuiabae & 34 & 68 & $20 m+8 s m+6 s t$ & Absent & Unknown & 2 & Arrombado bay-MT & Mariotto et al. (2009) \\
\hline Ancistrus cuiabae & 34 & 67 & $19 m+8 s m+6 s t+1 a$ & Absent & Unknown & 2 & Arrombado bay-MT & Mariotto et al. (2009) \\
\hline Ancistrus cuiabae & 34 & 66 & $18 m+8 s m+6 s t+2 a$ & Absent & Unknown & $\begin{array}{c}2 \\
(\mathrm{NOR})\end{array}$ & Arrombado bay-MT & Mariotto et al. (2009) \\
\hline Ancistrus cuiabae & 34 & 68 & $20 m+8 s m+6 s t$ & Absent & $3,6,9$ & 2 & Arrombado bay-MT & Mariotto et al. (2011) \\
\hline Ancistrus sp. Purus & 34 & 68 & $\begin{array}{l}21 m+11 s m+2 s t \\
20 m+2 s m+2 s t\end{array}$ & $\mathrm{XX} / \mathrm{XY}$ & $3,5,12,13$ & 4 & Purus river-AM & $\begin{array}{l}\text { de Oliveira et al. (2009) } \\
\text { Favarato et al. (2016) }\end{array}$ \\
\hline Ancistrus sp. Catalão & 34 & 68 & $22 m+8 s m+4 s t$ & $\mathrm{XX} / \mathrm{XY}$ & $3,6,7,12$ & 4 & Lake Catalão-AM & Favarato et al. (2016) \\
\hline Ancistrus sp. Trombetas & 38 & 73 & $22 m+8 s m+5 s t+3 a$ & Absent & Unknown & $\begin{array}{c}5 \\
(\mathrm{NOR})\end{array}$ & Trombetas river-PA & Oliveira et al. (2009) \\
\hline Ancistrus n.sp. 1 & 38 & 76 & $30 \mathrm{~m} / \mathrm{sm}+8 \mathrm{st}$ & Absent & Unknown & $\begin{array}{c}5 \\
(\mathrm{NOR})\end{array}$ & São Francisco river-AC & Alves et al. (2003) \\
\hline $\begin{array}{r}\text { Ancistrus dubius } \\
\text { Ancistrus sp. "Balbina” }\end{array}$ & $\begin{array}{l}+38 \\
339\end{array}$ & $\begin{array}{l}76 \\
78\end{array}$ & $\begin{array}{l}26 m+10 s m+2 s t \\
27 m+10 s m+2 s t\end{array}$ & $\mathrm{XX} / \mathrm{XY}_{1} \mathrm{Y}_{2}$ & 4 & 12 & Barretinho stream-AM & $\begin{array}{l}\text { de Oliveira et al. (2008) } \\
\text { Favarato et al. (2016) }\end{array}$ \\
\hline Ancistrus sp. 13 & 40 & 80 & $26 m+10 s m+4 s t$ & Absent & 5,15 & 18 & Salgadinho stream-MT & Mariotto et al. (2011) \\
\hline Ancistrus sp. 13 & 40 & 80 & $30 m+6 s m+4 s t$ & Absent & Unknown & 18 (NOR) & Salgadinho stream-MT & Mariotto et al. (2013) \\
\hline Ancistrus n.sp. 1 & $\begin{array}{l}739 \\
+40\end{array}$ & $\begin{array}{l}78 \\
80\end{array}$ & $\begin{array}{l}33 m+6 s m \\
34 m+6 s m\end{array}$ & $\mathrm{XX} / \mathrm{X} 0$ & Unknown & 20 (NOR) & Vermelho river-GO & Alves et al. (2006) \\
\hline Ancistrus cf. dubius & 42 & 84 & $24 m+10 s m+8 s t$ & Absent & Unknown & 16 (NOR) & Coxipó river-MT & Mariotto et al. (2006) \\
\hline Ancistrus cf. dubius & 42 & 84 & $24 m+10 s m+8 s t$ & $\mathrm{XX} / \mathrm{XY}$ & $4,14,16$ & 16 & Pari stream-MT & Mariotto et al. (2011) \\
\hline Ancistrus cf. dubius & 42 & 84 & $24 m+10 s m+8 s t$ & $\mathrm{XX} / \mathrm{XY}$ & $4,14,16$ & 16 & Flechas stream-MT & Mariotto et al. (2011) \\
\hline Ancistrus cf. dubius & 42 & 84 & $24 m+10 s m+8 s t$ & $\mathrm{XX} / \mathrm{XY}$ & $4,14,16$ & 16 & Fundo stream-MT & Mariotto et al. (2011) \\
\hline Ancistrus sp. Vermelho & 42 & 78 & $26 m+6 s m+4 s t+6 a$ & Absent & Unknown & 20 (NOR) & Demeni river-AM & de Oliveira et al. (2009) \\
\hline Ancistrus sp. & 42 & 84 & $18 m+16 s m+8 s t$ & Absent & $1,10^{*}$ & 10 & Criminoso stream-MS & Prizon et al. (2016) \\
\hline Ancistrus cf. dubius & 44 & 72 & $18 m+10 s m+16 s t / a$ & $\mathrm{ZZ/ZW}$ & Unknown & 13 (NOR) & $\begin{array}{l}\text { Serra das Araras stream- } \\
\text { MT }\end{array}$ & Mariotto et al. (2004) \\
\hline Ancistrus sp. 08 & 44 & 80 & $18 m+10 s m+8 s t+8 a$ & $\mathrm{ZZ/ZW}$ & 1,13 & 13 & Currupira river-MT & Mariotto et al. (2011) \\
\hline $\begin{array}{r}\text { Ancistrus maximus } \\
\text { Ancistrus sp. Macoari }\end{array}$ & 46 & $\begin{array}{l}81 \\
+82\end{array}$ & $\begin{array}{l}18 m+11 s m+6 s t+11 a \\
18 m+12 s m+6 s t+10 a\end{array}$ & $\mathrm{XX} / \mathrm{XY}$ & 19 & 19 & Branco river-RR & $\begin{array}{l}\text { Oliveira et al. (2006) } \\
\text { Favarato et al. (2016) }\end{array}$ \\
\hline Ancistrus abilhoai & 48 & 90 & $22 m+14 s m+6 s t+6 a$ & Absent & 13 & 13 & Iguaçu river-PR & Ribeiro et al. (2015) \\
\hline Ancistrus ranunculus & 48 & 82 & $\begin{array}{l}20 m+8 s m+6 s t+14 a \\
19 m+9 s m+6 s t+14 a\end{array}$ & $\mathrm{ZZ/ZW}$ & 16 & 16 & Xingu river-PA & $\begin{array}{l}\text { de Oliveira et al. (2007) } \\
\text { Favarato et al. (2016) }\end{array}$ \\
\hline Ancistrus aguaboensis & 50 & 80 & $16 m+10 s m+4 s t+20 a$ & Absent & $2,21,25$ & 25 & $\begin{array}{l}\text { Ribeirão Bandeirinha } \\
\text { river-GO }\end{array}$ & Present study \\
\hline Ancistrus sp. 06 & 50 & 86 & $18 m+10 s m+8 s t+14 a$ & Absent & 21 & 21 & Matrixã river-MT & $\begin{array}{l}\text { Mariotto et al. (2011, } \\
\text { 2013) }\end{array}$ \\
\hline Ancistrus tombador & 50 & 84 & $14 m+12 s m+8 s t+16 a$ & Absent & Unknown & 21 (NOR) & Preto river-MT & Mariotto et al. (2013) \\
\hline Ancistrus cirrhosus & 50 & 86 & $10 m+14 s m+12 s t+14 a$ & Absent & $1,18,23$ & 17 & $\begin{array}{l}\text { Arroyo San Juan-Posadas } \\
\text { (Argentina) }\end{array}$ & Prizon et al. (2017) \\
\hline Ancistrus taunayi & 50 & 92 & $22 m+10 s m+10 s t+8 a$ & $\mathrm{ZZ/ZW}$ & 21 & 24 & Cascalho stream-SC & Konerat et al. (2015) \\
\hline Ancistrus sp. & 50 & 88 & $20 m+12 s m+6 s t+12 a$ & Absent & $4,13,15,18$ & 13 & Unknown & Barros et al. (2017) \\
\hline $\begin{array}{r}\text { Ancistrus sp. "Mourão } \\
\text { River" }\end{array}$ & 50 & 92 & $12 m+18 s m+12 s t+8 a$ & Absent & $1,14,19,20$ & 12 & Mourão river-PR & Prizon et al. (2017) \\
\hline Ancistrus sp. "19 Stream” & 50 & 92 & $\begin{array}{l}11 m+18 s m+13 s t+8 a \\
112 m+18 s m+12 s t+8 a\end{array}$ & $\mathrm{XX} / \mathrm{XY}$ & $\begin{array}{l}1,12,15,20 \\
22,25\end{array}$ & 12 & Stream 19-PR & Prizon et al. (2017) \\
\hline $\begin{array}{r}\text { Ancistrus sp. "Keller } \\
\text { River" }\end{array}$ & 50 & 92 & $\begin{array}{l}11 m+18 s m+13 s t+8 a \\
12 m+18 s m+12 s t+8 a\end{array}$ & $\mathrm{XX} / \mathrm{XY}$ & $1,12,15,20,25$ & 12 & Keller river-PR & Prizon et al. (2017) \\
\hline $\begin{array}{r}\text { Ancistrus sp. } \\
\text { "SãoFrancisco } \\
\text { Verdadeiro River" }\end{array}$ & 50 & 94 & $14 m+16 s m+14 s t+6 a$ & Absent & $1,15,18,21$ & 18 & $\begin{array}{l}\text { São Francisco Verdadeiro } \\
\text { river-PR }\end{array}$ & Prizon et al. (2017) \\
\hline
\end{tabular}


TABLE 1 I (Continued)

\begin{tabular}{|c|c|c|c|c|c|c|c|c|}
\hline Species & 2n & FN & Karyotype formula & $\begin{array}{c}\text { Sex } \\
\text { chromosome } \\
\text { system }\end{array}$ & rDNA $5 S$ (pair) & $\begin{array}{l}\text { rDNA } \\
\text { 18S } \\
\text { (pair) }\end{array}$ & Localization & Reference \\
\hline $\begin{array}{r}\text { Ancistrus sp. "Ocoí } \\
\text { River" }\end{array}$ & 50 & 94 & $10 m+18 s m+16 s t+6 a$ & Absent & $18,21,22$ & 18 & Ocoí river-PR & Prizon et al. (2017) \\
\hline $\begin{array}{r}\text { Ancistrus sp. "São } \\
\text { Francisco Falso River" }\end{array}$ & 50 & 94 & $10 m+18 s m+16 s t+6 a$ & Absent & $11,14,18,19$ & 18 & $\begin{array}{l}\text { São Francisco Falso } \\
\text { river-PR }\end{array}$ & Prizon et al. (2017) \\
\hline Ancistrus cf. multispinis & 52 & 84 & $16 m+10 s m+6 s t+20 a$ & Absent & 21,25 & 24 & Ribeirão Grande river-SP & Present study \\
\hline Ancistrus sp. & 52 & 76 & $12 m+10 s m+30 s t / a$ & Absent & 13 & 3,14 & Angra dos Reis-SP & Reis et al. (2012) \\
\hline Ancistrus n.sp. 2 & 52 & 90 & $10 m+16 s m+12 s t+14 a$ & Absent & Unknown & 15 (NOR) & Garuva river-SC & Alves et al. (2006) \\
\hline Ancistrus sp. 04 & 52 & 82 & $16 m+8 s m+6 s t+22 a$ & Absent & Unknown & 22 (NOR) & Sepotuba river -MT & Mariotto et al. (2013) \\
\hline Ancistrus n.sp. 2 & 52 & 84 & $32 \mathrm{~m} / \mathrm{sm}+20 \mathrm{st} / \mathrm{a}$ & Absent & Unknown & 24 (NOR) & Betari river-SP & Alves et al. (2003) \\
\hline Ancistrus multispinnis & 52 & 80 & $28 \mathrm{~m} / \mathrm{sm}+24 \mathrm{st} / \mathrm{a}$ & Absent & Unknown & 17 (NOR) & Itapocu river-SC & Alves et al. (2003) \\
\hline $\begin{array}{r}\text { Ancistrus aff. } \\
\text { dolichopterus } \\
\text { Ancistrus sp. "Piagaçu" }\end{array}$ & 52 & $\begin{array}{l}878 \\
+79\end{array}$ & $\begin{array}{l}16 m+8 s m+2 s t+26 a \\
16 m+9 s m+2 s t+25 a\end{array}$ & $\mathrm{ZZ/ZW}$ & $\begin{array}{l}1,5,9,14,15,20 \\
22,24,25,26\end{array}$ & 26 & Purus river-AM & $\begin{array}{l}\text { de Oliveira et al. (2007) } \\
\text { Favarato et al. (2016) }\end{array}$ \\
\hline Ancistrus sp. Dimona & 52 & 78 & $16 m+8 s m+2 s t+26 a$ & Absent & Unknown & 13 (NOR) & $\begin{array}{l}\text { Fazenda Dimona stream- } \\
\text { AM }\end{array}$ & de Oliveira et al. (2009) \\
\hline Ancistrus sp. 4 & 52 & 82 & $16 m+8 s m+6 s t+22 a$ & Absent & $17,25,26^{*}$ & 22 & Sepotuba river-MT & $\begin{array}{l}\text { Mariotto et al. (2011, } \\
\text { 2013) }\end{array}$ \\
\hline $\begin{array}{l}\text { Ancistrus dolichopterus } \\
\text { Ancistrus sp. "Barcelos" }\end{array}$ & 52 & $\begin{array}{l}880 \\
+79\end{array}$ & $\begin{array}{l}12 m+12 s m+4 s t+24 a \\
11 m+12 s m+4 s t+25 a\end{array}$ & $\begin{array}{l}\mathrm{Z}_{1} \mathrm{Z}_{1} \mathrm{Z}_{2} \mathrm{Z}_{2} / \\
\mathrm{Z}_{1} \mathrm{Z}_{2} \mathrm{~W}_{1} \mathrm{~W}_{2}\end{array}$ & $\begin{array}{c}1,2,6,8,9,15 \\
16,18,19,20,23, \\
24,26\end{array}$ & 23 & Demeni river-AM & $\begin{array}{l}\text { de Oliveira et al. (2008) } \\
\text { Favarato et al. (2016) }\end{array}$ \\
\hline Ancistrus claro & 54 & 84 & $14 m+8 s m+8 s t+24 a$ & Absent & $4,19,21$ & 21 & Coxipó river-MT & $\begin{array}{l}\text { Mariotto et al. (2011, } \\
\text { 2013) }\end{array}$ \\
\hline Ancistrus sp. 03 & 54 & 84 & $14 m+8 s m+8 s t+24 a$ & Absent & Unknown & 21 (NOR) & Pari stream-MT & Mariotto et al. (2013) \\
\hline Ancistrus sp. 01 & 54 & 84 & $14 m+8 s m+8 s t+24 a$ & Absent & Unknown & 21 (NOR) & Pipa stream-MT & Mariotto et al. (2013) \\
\hline
\end{tabular}

compared in order to add information to understand the chromosomal evolution in the genus and contribute to taxonomic and systematic aspects.

\section{MATERIAL AND METHODS}

Species analyzed. Twenty five specimens (13 males and 12 females) of Ancistrus cf. multispinis (Regan, 1912) from Ribeirão Grande river, Paraíba do Sul basin (Pindamonhangaba-SP, $22^{\circ} 47^{\prime} 8^{\prime \prime S}$ and $45^{\circ} 27^{\prime \prime} 19^{\prime \prime W}$ ) and 20 specimens (10 males and 10 females) of Ancistrus aguaboensis Fisch-Muller, Mazzoni, Weber, 2001 from

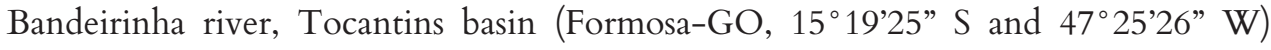
were cytogenetically analyzed. Specimens were deposited in the Coleção Ictiológica do Núcleo de Pesquisas em Limnologia, Ictiologia e Aquicultura (Nupélia) of the Universidade Estadual de Maringá, Maringá, Brazil (voucher numbers: Ancistrus aguaboensis, NUP 22305; Ancistrus cf. multispinis, NUP 22308).

Conventional cytogenetic procedures. The chromosomes were obtained from the air-drying method according to Bertollo et al. (2015). Detection of the constitutive heterochromatin was performed by C-banding according to Sumner (1972) and the nucleolar organizer regions (NORs) were detected by silver nitrate staining (Howell, Black, 1980). For karyotype assembly, homologs chromosomes were paired and grouped into metacentric (m), submetacentric (sm), subtelocentric (st) and acrocentric (a), according to Levan et al. (1964). To establish the fundamental number (FN), we 
considered the $\mathrm{m}$, sm and st chromosomes as two arms, and acrocentric chromosomes were considered as a single arm. About 30 cells with chromosomes in metaphase were analyzed for each species/method.

DNA extraction and isolation of repetitive DNAs. Genomic DNA was extracted from liver using Phenol-Chloroform method (Sambrook et al., 2001). Genomic DNA of both species was used as template in Polymerase Chain Reactions (PCRs) to obtain 5SrDNA sequences, using the following primers: 5Sa (5'- TACGCCCGATCTCGTCCGATC -3') and 5Sb (5'- CAGGCTGGTATGGCCGTAAGC -3') (Martins et al., 1999). The amplification reaction followed Barros et al. (2017) protocol. Agarose gel electrophoresis evidenced DNA fragments of approximately $1200 \mathrm{bp}$, which were isolated ("PCR DNA and Gel Band Purification Kit" - GE Healthcare) and cloned ("InsTAclone PCR Cloning Kit" - Promega), following the manufacturers' instructions. The $5 \mathrm{~S}$ rDNA clones were sequenced (ABI-Prism 3500 Genetic Analyzer - Applied Biosystems). The obtained sequences were analyzed by BIOEDIT 5.0.9 (Hall, 1999), then submitted to an identity analysis on BLAST (http://blast.ncbi.nlm.nih.gov/Blast.cgi), Rfam (https://rfam.xfam. org/) and CENSOR (www.girinst.org/censor/index.php).

Fluorescence in situ hybridization (FISH). The FISH procedures were performed following Pinkel et al. (1986) protocol, with stringency 77\% $(2.5 \mathrm{ng} / \mu \mathrm{L}$ probe, $50 \%$ formamide, 2 SSC, $10 \%$ dextran sulfate, at $37{ }^{\circ} \mathrm{C}$ for $16 \mathrm{~h}$ ). It was used the following probes: 18S rDNA (Hatanaka, Galetti Junior, 2004), 5S rDNA (1200 bp DNA fragment amplified by PCR) and the general telomeric sequence of vertebrates (TTAGGG)n (Ijdo et al., 1991). The probes 5S rDNA and (TTAGGG)n were labeled by PCR using digoxigenin 11-dUTP (Jena Bioscience); $18 \mathrm{~S}$ rDNA probe was labeled with biotin through the nick translation technique ("Biotin16 NT Labeling Kit" - Jena Bioscience). For signal detection, the antibodies Streptavidin Alexa Fluor 488 (Molecular Probes) and antidigoxigenin-rhodamine (Roche Applied Science) were applied. Chromosomes were counterstained with 4',6-diamidino-2-phenylindole (DAPI $0.2 \mu \mathrm{gmL}^{-1}$ ) in mounting medium Vectashield (Vector) and analyzed under an epifluorescence microscope Olympus BX51, coupled to the Olympus DP-72 camera with the DP2-BSW software. The best images were photographed, and karyotypes edited using Adobe Photoshop CS6.

\section{RESULTS}

Karyotypic description. Ancistrus aguaboensis presented $2 \mathrm{n}=50$ chromosomes, a karyotype formula arranged in $16 \mathrm{~m}+10 \mathrm{sm}+4 \mathrm{st}+20 \mathrm{a}, \mathrm{FN}=80$ and, without sex chromosome heteromorphism (Fig. 1A). C-banding revealed blocks of constitutive heterochromatin located on the centromeric and terminal regions of all chromosomes, in addition to one block on the pericentromeric region for the pair $\mathrm{m} 2$, on the interstitial long arm of the sm 9 and a large block on the terminal region of one member of the chromosome pair 18 (Fig. 1B). NORs sites were located on the short arms of acrocentric pair 25 (Fig. 1B, box).

Ancistrus cf. multispinis presented $2 \mathrm{n}=52$ chromosomes, a karyotype formula arranged in $16 \mathrm{~m}+10 \mathrm{sm}+6 \mathrm{st}+20 \mathrm{a}, \mathrm{FN}=84$ and, no heteromorphism of sex chromosomes 
was detected (Fig. 1C). The heterochromatin bands were located on the subterminal regions of the short arms of chromosomes pairs 1,2, 3 and 10; in addition to blocks of heterochromatin on the subterminal regions of the long arms of chromosomes pairs 13, 17, 18 and 20, on the interstitial region of chromosome pair 23, and on one member of each homologs chromosome pairs 25 and 26 (Fig. 1D). NORs sites were visualized on the short arms of the acrocentric pair 24 (Fig. 1D, box).

In situ localization of rDNAs and telomeric sites. FISH mapping of $5 \mathrm{~S}$ rDNA probe in chromosomes of $A$. aguaboensis showed three chromosomal sites: in pericentromeric regions of the short arms of chromosome pairs 2 and 25, and a subterminal site on the acrocentric 21 (Fig. 2A). In situ localization of $18 \mathrm{~S}$ rDNA sites evidenced signals on the subterminal region of the short arms of chromosome pair 25, syntenic with 5S rDNA sites (Fig. 2A). FISH mapping of (TTAGGG)n sequence showed telomeres regions marked (Fig. 2B), without ITS vestiges.

In situ localization of the 5S rDNA in A.cf. multispinis revealed sites on the subterminal regions of the short arms of acrocentric pairs 21 and 25, while 18S rDNA sites were located on the subterminal region of the short arms of acrocentric pair 24, which showed a variation in cistron size among the homologs (Fig. 2C). The FISH performed using telomeric sequence probes revealed only terminal chromosomal signals (Fig. 2D).
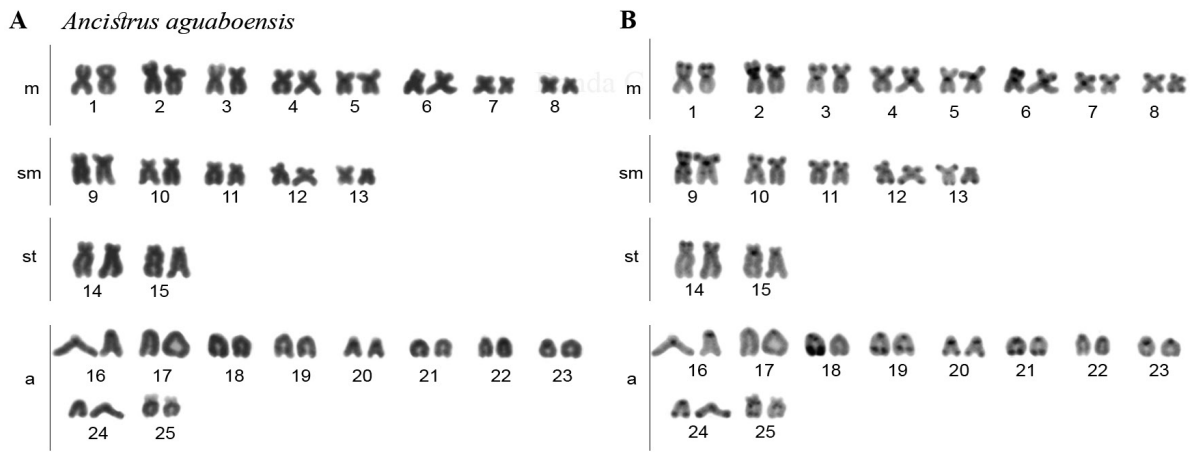

C Ancistrus cf. multispinis

D
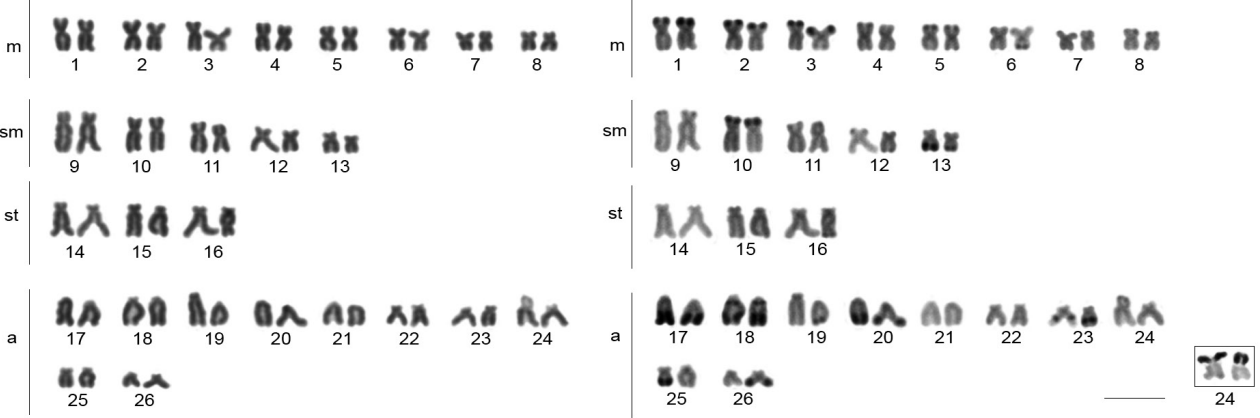

FIGURE 1 I Karyotypes of Ancistrus aguaboensis (A-B) and Ancistrus cf. multispinis (C-D) submitted do Giemsa staining $(\mathbf{A}-\mathbf{C})$ and C-banding $(\mathbf{B}-\mathbf{D})$. The chromosomes pairs with NORs sites are evidenced in the figure details (boxes). Bar $=10 \mu \mathrm{m}$. 
Analysis of 5S rDNA sequences. The 1193 bp-long 5S rDNA sequence obtained from A. aguaboensis (GenBank accession no. MT018470) presented 95\% identity with 5S rDNA gene of Symphysodon sp. (GenBank accession no. KP715274.1). This sequence shows an $120 \mathrm{bp}$ open reading frame (ORF), $1073 \mathrm{bp}$ of the non-transcribed spacer (NTS), an internal promoter comprising box A (47 - $59 \mathrm{bp})$, the intermediate element (IE) and the box C (78 - $95 \mathrm{bp}$ ) and, a poli-T cluster (downstream from transcribed region), a TATA-like region (-36 to -33$)$, a GC box $(-17$ to -15$)$ and a Citosin -1 . The analyses using the CENSOR software revealed a $30 \mathrm{bp}$ DNA fragment (1048 to 1078 bp) with $90.62 \%$ identity with the transposable element (TE) Helitron from Oryza sativa (HELITRON3_OS).

The 1082 bp-long 5S rDNA sequence obtained from $A$. cf. multispinis (GenBank accession no. MT018471) showed 98\% identity with 5S rDNA from Symphysodon sp. (GenBank accession no. KP715274.1). This sequence presents an $120 \mathrm{bp}$ ORF and a 962 bp NTS. The internal promoter comprising box A (47 - 59 bp), IE and the box C (79 - $96 \mathrm{bp}$ ). The poli-T cluster (downstream from transcribed region), the TATA-like region (-33 to -26$)$, GC box (-17 to -16$)$ and a Citosin -1 were also detected. Analyses by CENSOR software revealed a 76 bp DNA fragment (736 to 812 bp) with $78.21 \%$ identity with the TE $h A T$ from Salmo salar ( $h A T-35 N 1 \_S S a$ ). According to Rfam, the obtained $5 \mathrm{~S}$ rDNAs have identity to $5 \mathrm{~S}$ rRNAs between the segments 1-117, E-value = $4.2^{-19}$ for $A$. aguaboensis and E-value $=1.3^{-23}$ for $A$. cf. multispinis.

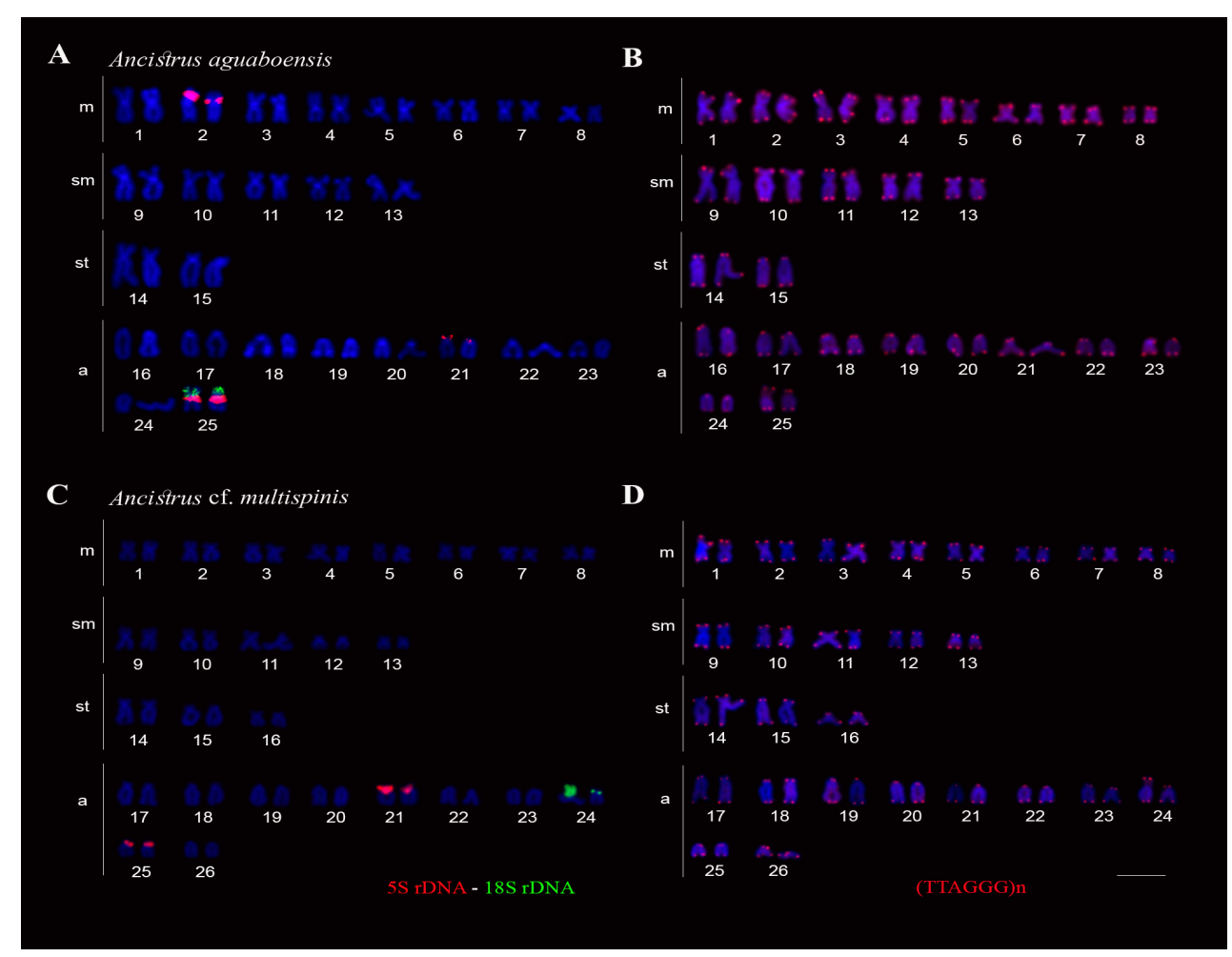

FIGURE 2 I Karyotypes of Ancistrus aguaboensis (A-B) and Ancistrus cf. multispinis (C-D) submitted to FISH using 5S rDNA, 18S rDNA and (TTAGGG)n probes. In (A-C), 5 S rDNA (in red) and 18S rDNA (in green) sites; in (B-D), terminal red markers evidenced (TAGGG)n sites. Bar $=10 \mu \mathrm{m}$. 


\section{DISCUSSION}

Ancistrini and Hypostomini tribes show a wide range of $2 \mathrm{n}$ and karyotypes among their representatives (Bueno et al., 2012, 2018; Traldi et al., 2012; Lorscheider et al., 2018). Hypostomini presents high $2 \mathrm{n}$ values and diversified karyotypes, whilst in Ancistrini, numerous species of Ancistrus tend for the 2n reduction (Mariotto et al., 2011; Barros et al., 2017; Bueno et al., 2018). Ancistrus cf. multispinis exhibits $2 \mathrm{n}=52$ chromosomes with half of the chromosomes carrying st/a morphology, while $A$. aguaboensis has $2 \mathrm{n}$ $=50$ chromosomes and $48 \%$ of its are st/a chromosomes. Bueno et al. (2018) showed that species of Ancistrus with 2 n close to 52 chromosomes have about $50 \%$ of st/a chromosomes in their karyotypes, while species with smaller $2 \mathrm{n}$ have considerably lower amounts of chromosomes with this morphology. Corroborating this proposal, the occurrence of fusion events of st/a chromosomes leads to the formation of $\mathrm{m} / \mathrm{sm}$ chromosomes, and consequent reduction of $2 \mathrm{n}$ in some species of Ancistrus (Mariotto et al., 2011; Favarato et al., 2016; Barros et al., 2017).

Ancistrus cf. multispinis specimens (Ribeirão Grande, Paraíba do Sul basin) analyzed in this study share $2 \mathrm{n}=52$ chromosomes with $A$. multispinis of the Itapocu river from the coastal basin (Tab. 1, Alves et al., 2003). However, differences in karyotype formulas between the two populations indicate microstructural chromosomal changes in allopatric populations. The absence of ITS vestiges also corroborates the indication of a conserved karyotype for the species. Ancistrus aguaboensis has its first karyotype description in this study, and $2 \mathrm{n}=50$ chromosomes suggests a numerical reduction by centric fusion. Aiming the location of ITS vestiges in fused chromosomes, few species of Ancistrus had the detection of (TTAGGG)n sequence probes in their genome (Favarato et al., 2016; Barros et al., 2017). In Ancistrus sp. (Barra Grande river, Paraná State, Ivaí basin), an ITS and 5S rDNA pseudogene were colocated on the metacentric pair 1 (Barros et al., 2017), as observed on the chromosome pair $\mathrm{m} 2$ of $A$. aguaboensis. In A. aguaboensis, no vestige of ITS was detected on the $\mathrm{m} / \mathrm{sm}$ chromosomes, which may be a result of the loss of these ITS during the fusion event (Meyne et al., 1990). However, since EBRs can be reused in karyotype evolution (Pevzner, Tesler, 2003), the presence of a 5S rDNA site in the proximal region of pair $\mathrm{m} 2$ indicate its origin from centric fusion with consequent loss of (TTAGGG)n sequences.

The distribution of heterochromatin in karyotypes is a feature widely evaluated in fishes (Kantek et al., 2009; Vicari et al., 2010). The location of chromosome-specific heterochromatic blocks can be useful and collaborate in the recognition of $\mathrm{Rb}$ fusion points (Rosa et al., 2012; Barros et al., 2017; Glugoski et al., 2018), or in the recognition of heteromorphic sex chromosomes (de Oliveira et al., 2007, 2008, 2009; Mariotto et al., 2011; Konerat et al., 2015; Favarato et al., 2016; Schemberger et al., 2019). Ancistrus cf. multispinis and $A$. aguaboensis presented large heterochromatic blocks in some chromosomal pairs, however, with no indication of sex chromosome heteromorphisms. The presence of large heterochromatic blocks is a feature widely shared in Ancistrus (Mariotto et al., 2011; Konerat et al., 2015; Favarato et al., 2016), whereas the absence of large heterochromatin blocks has been described to be a plesiomorphic characteristic in Loricariidae (Ziemniczak et al., 2012).

A single chromosome pair carrying $45 \mathrm{~S}$ rDNA (NOR) is a characteristic shared in all analyzed Ancistrus species (Bueno et al., 2018). Ancistrus cf. multispinis and A. aguaboensis 
also had only a single pair carrying the 45S rDNA, but on different chromosomes. While A. cf. multispinis did not present co-located 45S/5S rDNAs, in A. aguaboensis these clusters were located in synteny in an acrocentric pair. In other Ancistrus species, the location of the $45 \mathrm{~S}$ rDNA has also been shown to be widely varied (see Tab. 1). The $45 \mathrm{~S}$ rDNAs sites in different chromosomal locations, in chromosomes pairs showing different sizes and morphologies and, in condition of synteny to the 5S rDNA, indicate several transpositions and/or other structural events involving the $45 \mathrm{~S}$ rDNA in Ancistrus. Hence, the $45 \mathrm{~S}$ rDNA site was considered an important cytotaxonomic marker in the group due to its wide chromosomal location variation, being in innumerous cases, species-specific (Mariotto et al., 2011).

While the 45S rDNA is located in a single chromosome pair in Ancistrus, the 5S rDNA can be present in a large number of chromosomal sites (ranging from 1 to 13 chromosome pairs) in the different species analyzed (see Tab. 1). Barros et al. (2017) proposed the dispersion of $5 \mathrm{~S}$ rDNAs, and their pseudogenes, in subterminal regions of st/a chromosomes. EBRs located close to 5S rDNA pseudogenes could promote DSB and $\mathrm{Rb}$ fusion events (Barros et al., 2017). In fact, A. cf. multispinis and A. aguaboensis presented $5 \mathrm{~S}$ rDNA sites in the subterminal regions of acrocentric pairs. In addition, $A$. aguaboensis presented $5 \mathrm{~S}$ rDNA sequences at proximal region in the pair $\mathrm{m} 2$. Variations in the $5 \mathrm{~S}$ rDNA location occurs in Ancistrus species, but the proximal $5 \mathrm{~S}$ rDNA location in heterochromatic regions, with or without ITS vestiges, may explain a part of the $\mathrm{Rb}$ fusions present in the genus.

Previous cytogenetic studies in Trichomycteridae, Neoplecostominae and Hypoptopomatinae species proposed that the 45S/5S rDNA syntenic condition was present in the karyotypes of sister group for Loricariidae (Ziemniczak et al., 2012). Syntenic condition of rDNAs is widely visualized in karyotypes of Loricariidae representatives (Kavalco et al., 2004; Mariotto et al., 2011; Ziemniczak et al., 2012; Traldi et al., 2013; Bueno et al., 2014; Favarato et al., 2016; Barros et al., 2017). Analyzing the location of chromosome types and the position of rDNAs synteny sites in Ancistrini, it is more parsimonious to infer evolutionary recurrence indexes for this chromosome condition in this tribe. In fact, when evaluating the pattern of the karyotype distribution of rDNAs in Ancistrus, although it may be an allusive proposal, it is possible to corroborate the proposal of Barros et al. (2017), which rDNAs pseudogenes can organize EBRs and, these EBRs, have an evolutionary re-use to generate chromosome diversification in the group.

The analysis of the $5 \mathrm{~S}$ rDNAs sequences of $A$. cf. multispinis and A. aguaboensis demonstrated that they have all the structures necessary for their function, although this analysis can be only predictive. Unlike the studies proposed by Barros et al. (2017) and Glugoski et al. (2018), 5S rDNA pseudogenes were not recovered in our analyzes. Pseudogenes are common in multigene families (Rebordinos et al., 2013). It is difficult to detect EBRs in multigene families, which depends of a large number of sequence analysis or the use of comparative genomics. Thus, the detailed assessment of the presence of EBRs in 5S rDNA pseudogenes/degenerated sequences still remains predictive. However, in Ancistrus species with $2 \mathrm{n} \leq 50$ chromosomes, the presence of $5 \mathrm{~S}$ rDNA sites on $\mathrm{m} / \mathrm{sm}$ chromosomes, originated from $\mathrm{Rb}$ fusion, could explain part of the chromosome diversification in the genus.

Ancistrus aguaboensis and A. cf. multispinis are found in sympatry and syntopy with species of Harttia punctata and Harttia carvalhoi, respectively. These species show 
karyotype diversity, with the absence of sex chromosomes in $A$. aguaboensis and $A$. cf. multispinis, however with the presence of multiple sex chromosomes systems in Harttia punctata $\left(\mathrm{X}_{1} \mathrm{X}_{1} \mathrm{X}_{2} \mathrm{X}_{2} / \mathrm{X}_{1} \mathrm{X}_{2} \mathrm{Y}\right)$ and in Harttia carvalhoi $\left(\mathrm{XX}_{\mathrm{X}} \mathrm{XY}_{1} \mathrm{Y}_{2}\right)$ (Blanco et al., 2013, 2014). These armored catfishes inhabit small tributaries, which favors the isolation of populations, providing events of chromosome rearrangements that could be more easily fixed. This cytogenetic differentiation may be functioning as a reproductive barrier between species, a fact confirmed by the absence of hybrid species.

The wide karyotype diversification present in Ancistrus (Bueno et al., 2018) is compatible with the fact that the group is diverse and specious (Lujan et al., 2015). Chromosome rearrangements promote important differences in the genomic sets of species, which could lead to meiotic incompatibilities (Navarro, Barton, 2003). Chromosome segregation failure and the ensuing production of unviable gametes due to the accumulation of chromosomal rearrangements might play an important role in speciation (Navarro, Barton, 2003; Faria, Navarro, 2010). In the same way, the genetic differences accumulated in divergent Ancistrus species may have helped in the diversification of this evolutionary lineage.

\section{ACKNOWLEDGMENTS}

This study was financed by FAPESP (Fundacão de Amparo à Pesquisa do Estado de São Paulo), CAPES (Coordenacão de Aperfeiçoamento de Pessoal de Nível Superior - Financial Code 001) and CNPq (Conselho Nacional de Desenvolvimento Científico e Tecnológico). The authors are grateful to ICMBio (Instituto Chico Mendes de Conservação da Biodiversidade - protocol number SISBIO 10538-1) for authorizing the capture of specimens.

\section{REFERENCES}

- Alves AL, Oliveira C, Foresti F. Karyotype variability in eight species of the subfamilies Loricariinae and Ancistrinae (Teleostei, Siluriformes, Loricariidae). Caryologia. 2003; 56(1):57-63. https://doi.or $\mathrm{g} / 10.1080 / 00087114.2003 .10589308$

- Alves AL, Oliveira C, Nirchio M, Granado A, Foresti F. Karyotypic relationship among the tribes of Hypostominae (Siluriformes: Loricariidae) with description of X0 sex chromosome system in a Neotropical fish species. Genetica. 2006; 128(1-3):1-9. https://doi.org/10.1007/ s10709-005-0715-1

- Armbruster JW. Phylogenetic relationships of the suckermouth armoured catfishes (Loricariidae) with emphasis on the Hypostominae and the Ancistrinae. Zool J Linn Soc. 2004; 141(1):1-80. https://doi.org/10.1111/j.10963642.2004.00109.x
- Armbruster JW. The genus Peckoltia with the description of two new species and a reanalysis of the phylogeny of the genera of the Hypostominae (Siluriformes: Loricariidae). Zootaxa. 2008; 1822:1-76. https://doi.org/10.11646/zootaxa.1822.1.1

- Artoni RF, Bertollo LAC. Trends in the Karyotype Evolution of Loricariidae Fish (Siluriformes). Hereditas. 2001; 134(3):20110. https://doi.org/10.1111/j.16015223.2001.00201.x

- Barbosa P, Pucci MB, Nogaroto V, Almeida MC, Artoni RF, Vicari MR. Karyotype analysis of three species of Corydoras (Siluriformes: Callichthyidae) from southern Brazil: rearranged karyotypes and cytotaxonomy. Neotrop Ichthyol. 2017; 15(1):e160056. https://doi. org/10.1590/1982-0224-20160056 
- Barros AV, Wolski MAV, Nogaroto V, Almeida MC, Moreira-Filho O, Vicari MR. Fragile sites, dysfunctional telomere and chromosome fusions: what is 5S rDNA role? Gene. 2017; 608:20-27. https://doi. org/10.1016/j.gene.2017.01.013

- Bellafronte E, Margarido VP, MoreiraFilho 0. Cytotaxonomy of Parodon nasus and Parodon tortuosus (Pisces, Characiformes). A case of synonymy confirmed by cytogenetic analyses. Genet Mol Biol. 2005; 28(4):710-16. https://doi. org/10.1590/S1415-47572005000500010

- Bertollo LAC, Cioffi MB, Moreira-Filho O. Direct chromosome preparation from freshwater teleost fishes. In: Ozouf-Costaz C, Pisano E, Foresti F, Almeida Toledo LF, editors. Fish cytogenetic techniques (RayFin Fishes and Chondrichthyans). Enfield USA: CRC Press; 2015. p.21-26. https://doi. org/10.1201/b18534-4

- Blanco DR, Vicari MR, Lui RL, Bertollo LA, Traldi JB, MoreiraFilho $\mathbf{0}$. The role of the Robertsonian rearrangements in the origin of the $\mathrm{XX} /$ $\mathrm{XY}_{1} \mathrm{Y}_{2}$ sex chromosome system and in the chromosomal differentiation in Harttia species (Siluriformes, Loricariidae). Rev Fish Biol Fish. 2013; 23:127-34. https://doi. org/10.1007/s11160-012-9283-5

- Blanco DR, Vicari MR, Lui RL, Artoni RF, Almeida MC, Traldi JB, Margarido VP, Moreira- Filho O. Origin of the $\mathrm{X}_{1} \mathrm{X}_{1} \mathrm{X}_{2} \mathrm{X}_{2} /$ $\mathrm{X}_{1} \mathrm{X}_{2} \mathrm{Y}$ sex chromosome system of Harttia punctata (Siluriformes, Loricariidae) inferred from chromosome painting and FISH with ribosomal DNA markers. Genetica; 2014; 142(2):119-26. https://doi. org/10.1007/s10709-014-9759-4

- Bueno V, Zawadzki CH, Margarido VP. Trends in chromosome evolution in the genus Hypostomus Lacépède, 1803 (Osteichthyes, Loricariidae): a new perspective about the correlation between diploid number and chromosomes types. Rev Fish Biol Fish. 2012; 22:241-50. https:// doi.org/10.1007/s11160-011-9215-9

- Bueno V, Venere PC, Konerat JT, Zawadzki CH, Vicari MR, Margarido VP. Physical mapping of the $5 \mathrm{~S}$ and 18S rDNA in ten species of Hypostomus Lacépède 1803 (Siluriformes: Loricariidae): Evolutionary tendencies in the genus. Sci World J. 2014; 2014(3):1-8. https://doi. org/10.1155/2014/943825
- Bueno V, Konerat JT, Zawadzki CH, Venere PC, Blanco DR, Margarido VP. Divergent chromosome evolution in Hypostominae Tribes (Siluriformes: Loricariidae): correlation of chromosomal data with morphological and molecular phylogenies. Zebrafish. 2018; 15(5):492503. https://doi.org/10.1089/zeb.2018.1612

- Charlesworth B, Snegowski P, Stephan $\mathbf{W}$. The evolutionary dynamics of repetitive DNA in eukaryotes. Nature. 1994; 371(6494):215-20. https://doi. org $/ 10.1038 / 371215 a 0$

- Errero-Porto F, Vieira MMR, Barbosa LM, Borin-Carvalho LA, Vicari MR, Portela-Castro ALB, Martins-Santos IC. Chromosomal Polymorphism in Rineloricaria Lanceolata Günther, 1868 (Loricariidae: Loricariinae) of the Paraguay Basin (Mato Grosso do Sul, Brazil): Evidence of Fusions and Their Consequences in the Population. Zebrafish. 2014; 11(4):318-24. https://doi.org/10.1089/ zeb.2014.0996

- Faria R, Navarro A. Chromosomal speciation revisited: Rearranging theory with pieces of evidence. Trends Ecol Evol. 2010; 25(11):660-69. https://doi. org/10.1016/j.tree.2010.07.008

- Favarato RM, Silva M, Oliveira RR, Artoni RF, Feldberg E, Matoso DA. Cytogenetic diversity and the evolutionary dynamics of rDNA genes and telomeric sequences in the Ancistrus genus (Loricariidae: Ancistrini). Zebrafish. 2016; 13(2):103-11. https://doi.org/10.1089/ zeb.2015.1140

- Ferraris Jr CJ. Checklist of catfishes, recent and fossil (Osteichthyes: Siluriformes), and catalogue of Siluriform primary types. Zootaxa. 2007; 1418:1-628. http://dx.doi. org/10.11646/zootaxa.1418.1.1

- Fricke R, Eschmeyer WN, Fong JD. Species by subfamily/ subfamily [Internet]. San Francisco: California Academy of Science; 2020. Available from: http:// researcharchive.calacademy.org/research/ ichthyology/catalog/SpeciesByFamily.asp

- Glugoski L, Giuliano-Caetano L, MoreiraFilho O, Vicari MR, Nogaroto V. Colocated $h A T$ transposable element and 5S rDNA in an interstitial telomeric sequence suggest the formation of Robertsonian fusion in armored catfish. Gene. 2018; 650:49-54. https://doi.org/10.1016/j. gene.2018.01.099 
- Hall TA. BioEdit: a user-friendly biological sequence alignment editor and analysis program for Windows 95/98/NT. Nucleic Acids Symp. 1999; 41:95-98. https://doi. org/10.14601/Phytopathol_Mediterr14998u1.29

- Hatanaka T, Galetti Jr. PM. Mapping of the $18 \mathrm{~S}$ and $5 \mathrm{~S}$ ribosomal RNA genes in the fish Prochilodus argenteus Agassiz, 1829 (Characiformes, Prochilodontidae). Genetica. 2004; 122(3): 239-44. https://doi. org/10.1007/s10709-004-2039-y

- Howell WM, Black DA. Controlled silverstaining of nucleolus organizer regions with a protective colloidal developer: a 1-step method. Experientia. 1980; 36(8):1014-15. https://doi.org/10.1007/ bf01953855

- Ijdo JW, Wells RA, Baldini A, Reeders ST. Improved telomere detection using a telomere repeat probe (TTAGGG)n generated by PCR. Nucleic Acids Res. 1991; 19(17):4780. https://doi.org/10.1093/ nar/19.17.4780

- Kantek DLZ, Vicari MR, Peres WAM, Cestari MM, Artoni RF, Bertollo LAC, Moreira-Filho O. Chromosomal location and distribution of As51 satellite DNA in five species of the genus Astyanax (Teleostei, Characidae, Incertae sedis). J Fish Biol. 2009; 75(2):408-21. https://doi. org/10.1111/j.1095-8649.2009.02333.x

- Kavalco KF, Pazza R, Bertollo LAC, Moreira-Filho O. Heterochromatin characterization of four fish species of the family Loricariidae (Siluriformes). Hereditas. 2004; 141(3):237-42. https://doi. org/10.1111/j.1601-5223.2004.01850.x

- Konerat JT, Bueno V, Margarido VP, Portela-Castro, ALB, Martins-Santos IC Diversity of Sex Chromosome Systems in Ancistrini (Loricariidae, Hypostominae): ZZ/ZW in Ancistrus taunayi Miranda Ribeiro, 1918. Cytogenet Genome Res. 2015; 146(4):306-10. https://doi. org/10.1159/000441431

- Levan A, Fredga K, Sandberg AA. Nomenclature for centromeric position on chromosomes. Hereditas. 1964; 52(2):20120. https://doi.org/10.1111/j.1601-5223.1964. tb01953.x

- Long EO, Dawid IB. Repeated genes in eukaryotes. Annu Rev Biochem. 1980; 49:727-64. https://doi.org/10.1146/annurev. bi.49.070180.003455
- Lorscheider CA, Oliveira JIN, Dulz TA, Nogaroto V, Martins-Santos IC, Vicari MR. Comparative Cytogenetics Among Three Sympatric Hypostomus Species (Siluriformes: Loricariidae): An Evolutionary Analysis in a High Endemic Region. Braz Arch Biol Technol. 2018; 61:e18180417. https://doi.org/10.1590/16784324-2018180417

- Lujan NK, Roach KA, Jacobsen D, Winemiller KO, Vargas VM, Ching VR, Maestre JA. Aquatic community structure across an Andes-to-Amazon fluvial gradient. J Biogeogr. 2013; 40(9):1715-28. https://doi.org/10.1111/jbi.12131

- Lujan NK, Armbruster JW, Lovejoy NR, López-Fernández H. Multilocus molecular phylogeny of the suckermouth armored catfishes (Siluriformes: Loricariidae) with a focus on subfamily Hypostominae. Mol Phylogenetics Evol. 2015; 82PtA:269-88. https://doi.org/10.1016/j.ympev.2014.08.020

- Mariotto S, Artoni RF, Miyazawa CS. Occurence of sexual chromosome, of the type ZZ/ZW, in Ancistrus cf. dubius (Loricariidae: Ancistrinae) of the Paraguay River Basin, Mato Grosso, Brazil. Caryologia. 2004; 57(4):327-31. https://doi. org/10.1080/00087114.2004.10589413

- Mariotto S, Miyazawa CS. Ancistrus cf. dubius (Siluriformes: Ancistrinae), a complex of species. 1. Chromosomal characterization of four populations and occurrence of sex chromosomes of the type XX/XY, in the Pantanal Basin of Mato Grosso, Brazil. Caryologia. 2006; 59(4):299304. https://doi.org/10.1080/00087114.2006 .10797929

- Mariotto S, Centofante L, Miyazawa CS, Bertollo LAC, Moreira-Filho 0. Chromosome polymorphism in Ancistrus cuiabae Knaack, 1999 (Siluriformes: Loricariidae: Ancistrini). Neotrop Ichthyol. 2009; 7(4):595-600. https://doi.org/10.1590/ S1679-62252009000400006

- Mariotto S, Centofante L, Vicari MR, Artoni RF, Moreira-Filho 0. Chromosomal diversification in ribosomal DNA sites in Ancistrus Kner, 1854 (Loricariidae, Ancistrini) from three hydrographic basins of Mato Grosso, Brazil. Comp Cytogenet. 2011; 5(4):289-300. https://doi.org/10.3897/CompCytogen. v5i4.1757 
- Mariotto S, Centofante L, MoreiraFilho 0. Diversity and chromosomal evolution in the genus Ancistrus Kner, 1854 (Loricariidae: Ancistrini) from three hydrographic basins of Mato Grosso State, Brazil. Neotrop Ichthyol. 2013; 11(1):125 - 31. https://doi.org/10.1590/S167962252013000100015

- Martins C, Galetti Jr PM. Chromosomal localization of 5S rDNA genes in Leporinus Fish (Anostomidae, Characiformes). Chromosome Res. 1999; 7(5):363-67. https://doi.org/10.1023/a:1009216030316

- Maxon R, Cohn R, Kedes L, Mohun T. Expression and organization of histone genes. Annu Rev Genet. 1983; 17:23977. https://doi.org/10.1146/annurev. ge.17.120183.001323

- Meyne J, Baker RJ, Hobart HH, Hsu TC, Ryder OA, Ward OG, Wiley JE, Wurster-Hill DH, Yates TL, Moyzis RK. Distribution of non-telomeric sites of the (TTAGGG)n telomeric sequence in vertebrate chromosomes. Chromosoma. 1990; 99(1):3-10. https://doi.org/10.1007/ bf01737283

- Nascimento VD, Coelho KA, Nogaroto V, Almeida RB, Ziemniczak K, Centofante L, Pavanelli CS, Torres RA, MoreiraFilho O, Vicari MR. Do multiple karyomorphs and population genetics of freshwater darter characines (Apareiodon affinis) indicate chromosomal speciation? Zool Anz. 2018; 272:93-103. https://doi. org/10.1016/j.jcz.2017.12.006

- Navarro A, Barton NH. Accumulating postzygotic isolation genes in parapatry: a new twist on chromosomal speciation. Evolution. 2003; 57(3):447-59. https://doi. org/10.1111/j.0014-3820.2003.tb01537.x

- de Oliveira RR, Souza IL, Venere PC. Karyotype description of three species of Loricariidae (Siluriformes) and occurrence of the ZZ/ZW sexual system in Hemiancistrus spilomma Cardoso \& Lucinda, 2003. Neotrop Ichthyol. 2006; 4(1):93- 97. https://doi.org/10.1590/S167962252006000100010

- de Oliveira RR, Feldberg E, Anjos MB, Zuanon J. Karyotype characterization and ZZ/ZW sex chromosome heteromorphism in two species of the catfish genus Ancistrus Kner, 1854 (Siluriformes: Loricariidae) from the Amazon basin. Neotrop Ichthyol. 2007; 5(3):301-06. https:// doi.org/10.1590/S1679-62252007000300010
- de Oliveira RR, Feldberg E, Anjos MB, Zuanon J. Occurrence of multiple sexual chromosomes $\left(\mathrm{XX} / \mathrm{XY}_{1} \mathrm{Y}_{2}\right.$ and $\mathrm{Z}_{1} \mathrm{Z}_{1} \mathrm{Z}_{2} \mathrm{Z}_{2}$ l $\mathrm{Z}_{1} \mathrm{Z}_{2} \mathrm{~W}_{1} \mathrm{~W}_{2}$ ) in catfishes of the genus Ancistrus (Siluriformes: Loricariidae) from the Amazon basin. Genetica. 2008; 134(2):243-49. https://doi.org/10.1007/ s10709-007-9231-9

- de Oliveira RR, Feldberg E, Anjos MB, Zuanon J. Mechanisms of chromosomal evolution and its possible relation to natural history characteristics in Ancistrus catfishes (Siluriformes: Loricariidae). J Fish Biol. 2009; 75(9):2209-25. https://doi. org/10.1111/j.1095-8649.2009.02450.x

- Oliveira MLM, Utsunomia R, Pansonato-Alves JC, Scacchetti PC, Primo CC, Vicari MR, Artoni RF, Centofante L, Moreira-Filho O, Oliveira C, Foresti F. Microstructural chromosome reorganization in the genus Trichomycterus (Siluriformes: Trichomycteridae). Neotrop Ichthyol. 2016; 14(2):e150084. https://doi.org/10.1590/19820224-20150084

- Pevzner PA, Tesler G. Human and mouse genomic sequences reveal extensive breakpoint reuse in mammalian evolution. Proc Natl Acad Sci USA. 2003; 100(13):7672-77. https://doi.org/10.1073/ pnas. 1330369100

- Pinkel D, Straume T, Gray JW. Cytogenetic analysis using quantitative, high-sensitivity, fluorescence hybridization. Proc Natl Acad Sci USA. 1986; 83(9):2934-38. https://doi.org/10.1073/ pnas.83.9.2934

- Primo CC, Glugoski L, Almeida MC, Zawadzki HC, Moreira-Filho O, Vicari MR, Nogaroto V. Mechanisms of chromosomal diversification in species of Rineloricaria (Actinopterygii: Siluriformes: Loricariidae). Zebrafish. 2017; 14(2):16168. https://doi.org/10.1089/zeb.2016.1386

- Primo CC, Glugoski L, Vicari MR, Nogaroto V. Chromosome Mapping and Molecular Characterization of the Tc1/Mariner Element in Rineloricaria (Siluriformes: Loricariidae). Braz Arch Biol Technol. 2018; 61:e18170623. https://doi. org/10.1590/1678-4324-2018170623 
- Prizon AC, Borin-Carvalho LA, Bruschi DP, Ribeiro MO, Barbosa LM, Ferreira GEB, Cius A, Zawadzki CH, PortelaCastro ALB. Cytogenetic data on Ancistrus sp. (Siluriformes, Loricariidae) of the Paraguay River basin (MS) sheds light on intrageneric karyotype diversification. Comp Cytogenet. 2016; 10(4):625-36. https://doi.org/10.3897/CompCytogen. v10i4.8532

- Prizon AC, Bruschi DP, Borin-Carvalho LA, Cius A, Barbosa LM, Ruiz HB, Zawadzki CH, Fenocchio AS, PortelaCastro ALB. Hidden diversity in the populations of the armored catfish Ancistrus Kner, 1854 (Loricariidae, Hypostominae) from the Paraná River basin revealed by molecular and cytogenetic data. Front Genet. 2017; 8:185. https://doi.org/10.3389/fgene.2017.00185

- Rebordinos L, Cross I, Merlo A. High evolutionary dynamism in 5S rDNA of fish: state of the art. Cytogenet Genome Res. 2013; 141(2-3):103-13. https://doi. org/10.1159/000354871

- Reis RE, Pereira EHL, Armbruster JH. Delturinae, a new loricariid catfish subfamily (Teleostei: Siluriformes), with revisions of Delterus and Hemipsilichthys. Zool J Linn Soc. 2006; 147(2):277-99. https:// doi.org/10.1111/j.1096-3642.2006.00229.x

- Reis DAR, Brandão KO, Toledo LFA, Pazza R, Kavalco KF. Localização física dos genes ribossomais $5 \mathrm{~S}$ e $18 \mathrm{~S}$ em Ancistrus sp. (Loricariidae: Ancistrini) de Angra dos Reis/RJ, Bacia dos Rios Costeiros. Evol Conserv Biodivers. 2012; 3:39-44.

- Ribeiro MO, Noleto RB, Lorscheider CA, Porto FE, Prizon AC, Zawadzki CH, Oliveira LC, Portela-Castro ALB. Cytogenetic description of Ancistrus abilhoai (Siluriformes: Loricariidae) from Iguaçu River basin, southern Brazil. Genet Mol Res. 2015; 14(2):4051-57. https://doi. org/10.4238/2015.April.27.20

- Rosa KO, Ziemniczak K, Barros AV, Nogaroto V, Almeida MC, Cestari MM, Artoni RF, Vicari MR. Numeric and structural chromosome polymorphism in Rineloricaria lima (Siluriformes: Loricariidae): fusion points carrying $5 \mathrm{~S}$ rDNA or telomere sequence vestiges. Rev Fish Biol Fish. 2012; 22:739-49. https://doi. org/10.1007/s11160-011-9250-6
- Sambrook J, Russell DW. Molecular cloning, a laboratory manual. New York: Cold Spring Harbor Laboratory Press; 2001.

- Schemberger MO, Nascimento VD, Coan R, Ramos E, Nogaroto V, Ziemniczak K, Valente GT, Moreira-Filho O, Martins C, Vicari MR. DNA transposon invasion and microsatellite accumulation guide $\mathrm{W}$ chromosome differentiation in a Neotropical fish genome. Chromosoma. 2019; 128(4):547-60. https://doi.org/10.1007/ s00412-019-00721-9

- Sumner AT. A simple technique for demonstrating centromeric heterochromatin. Exp Cell Res. 1972; 75(1):304-06. https://doi.org/10.1016/00144827(72)90558-7

- Traldi JB, Vicari MR, Blanco DR, Martinez JF, Artoni RF, MoreiraFilho O. First karyotype description of Hypostomus iheringii (Regan, 1908): a case of heterochromatic polymorphism. Comp Cytogen. 2012; 6(2):115-25. https://doi. org/10.3897/CompCytogen.v6i2.2595

- Traldi JB, Blanco DR, Vicari MR, Martinez JF, Lui RL, Barros AV, Artoni RF, Moreira-Filho O. Chromosomal diversity in Hypostomus (Siluriformes, Loricariidae) with emphasis on physical mapping of $18 \mathrm{~S}$ and 5S rDNA sites. Genet Mol Res. 2013; 12(1):463-71. https://doi. org/10.4238/2013.February.8.11

- Vicari MR, Almeida MC, Bertollo LAC, Moreira-Filho O, Artoni RF. Cytogenetic analysis and chromosomal characteristics of the polymorphic $18 \mathrm{~S}$ rDNA in the fish Prochilodus lineatus (Characiformes, Prochilodontidae). Genet Mol Biol. 2006; 29:621-25. https://doi.org/10.1590/S141547572006000400008

- Vicari MR, Nogaroto V, Noleto RB, Cestari, MM, Cioffi MB, Almeida MC, Moreira-Filho O, Bertollo LAC, Artoni RF. Satellite DNA and chromosomes in Neotropical fishes: Methods, applications and perspectives. J Fish Biol. 2010; 76(5):1094-116. https://doi.org/10.1111/ j.1095-8649.2010.02564.x

- Ziemniczak K, Barros AV, Rosa KO, Nogaroto V, Almeida MC, Cestari MM, Moreira-Filho O, Artoni RF, Vicari MR. Comparative cytogenetics of Loricariidae (Actinopterygii: Siluriformes): emphasis in Neoplecostominae and Hypoptopomatinae. Ital J Zool. 2012; 79(4):492-501. https://doi. org/10.1080/11250003.2012.676677 


\section{Neotropical lchthyology}

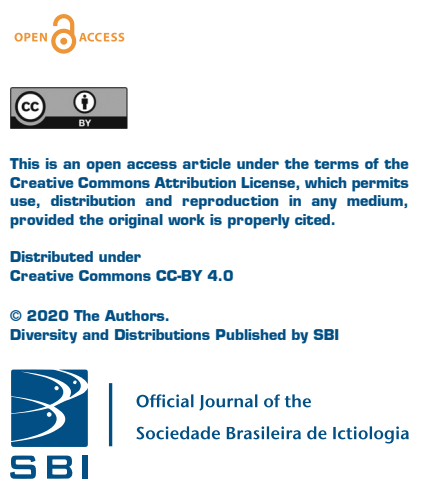

\section{AUTHOR'S CONTRIBUTION 주}

Larissa Glugoski: Conceptualization, Formal analysis, Investigation, Methodology, Writing-original draft. Geize Deon: Formal analysis, Investigation, Methodology.

Stephane Schott: Methodology.

Marcelo R. Vicari: Methodology, Project administration, Supervision, Writing-review \& editing.

Viviane Nogaroto: Methodology, Project administration, Supervision, Writing-review \& editing.

Orlando Moreira-Filho: Funding acquisition, Investigation, Project administration, Supervision, Writingreview \& editing.

\section{ETHICAL STATEMENT}

The research was approved by the Ethics Committee of Animal Usage (Process CEUA 028/2016) of the Universidade Estadual de Ponta Grossa.

\section{COMPETING INTERESTS}

The authors declare no competing interests.

\section{HOW TO CITE THIS ARTICLE}

- Glugoski L, Deon G, Schott S, Vicari MR, Nogaroto V, Moreira-Filho O. Comparative cytogenetic analyses in Ancistrus species (Siluriformes: Loricariidae). Neotrop Ichthyol. 2020; 18(2):e200013. https://doi.org/10.1590/1982-0224-2020-0013 